\title{
Utvikling av veiledningskompetanse i et læringsfellesskap
}

\author{
Frode Olav Haara ${ }^{1 *}$, Lene Hayden Taraldsen ${ }^{2}$, Eirik S. Jenssen ${ }^{3}$ \\ ${ }^{1}$ Høgskulen på Vestlandet, Institutt for språk, litteratur, matematikk og tolking \\ ${ }^{2}$ Høgskulen på Vestlandet, Institutt for språk, litteratur, matematikk og tolking \\ ${ }^{3} \mathrm{H} \emptyset$ gskulen på Vestlandet, Institutt for pedagogikk, religion og samfunnsfag \\ * Korrespondanse: frode.olav.haara@hvl.no
}

\section{Sammendrag}

I artikkelen ser vi på hvordan et fagmiljø kan videreutvikle kompetanse til å veilede gjennom erfaringsdeling og refleksjon rundt egen veilederrolle. Utvikling av veiledningskompetanse kobler vi til deltakelse i et læringsfellesskap og faktisk veiledning, knyttet til et veilederforum. Gjennom en innovativ bruk av narrativer som metodisk tilnærming eksemplifiserer vi ulike perspektiver ved veiledningsarbeid og utvikling av veiledningskompetanse i høyere utdanning.

Nøkkelord: veiledning; veilederforum; narrativ

\section{Introduksjon}

Tre år har gått siden grunnskolelærerutdanningene ble femårige, og fra høsten 2021 skal de første grunnskolelærerstudentene skrive en masteroppgave, under veiledning av en faglærer. Dette er en situasjon som trolig gir nye utfordringer for alle grunnskolelærerutdanningene i Norge. Ved matematikkseksjonen ved Høgskulen på Vestlandet (HVL) - Campus Sogndal, har vi behov for at veiledning av masteroppgaver fordeles på langt flere fagansatte enn i dag. Et påtrengende spørsmål er hvordan fagmiljøet møter denne utfordringen. Vårt svar ble å legge til rette for å utvikle veilederkompetansen hos lite erfarne veiledere gjennom veiledning på mindre studentoppgaver, $\mathrm{i}$ samarbeid med erfarne veiledere. FoU-oppgaven, som grunnskolelærerstudentene skal skrive i sitt tredje studieår, er en slik oppgave. Denne har et mindre omfang enn en masteroppgave, men byr på mange av de samme utfordringer for student og veileder. Samtidig så vi behovet for å utvikle en felles forståelse for veiledning og veiledningsaktivitet blant veilederne involvert i FoU-oppgaven, gjennom erfaringsdeling og refleksjon rundt veiledning og veilederrollen. Artikkelen belyser derfor denne problemstillingen:

Hvordan kan et faglig læringsfellesskap utvikle kompetanse til å veilede gjennom erfaringsdeling og refleksjon rundt egen veilederrolle?

Målet med artikkelen er å formidle hvordan vi har arbeidet for å videreutvikle veiledningskompetanse i vårt læringsfellesskap. 


\section{Begrepsklargjøringer og teoretisk forankring}

Profesjonelle læringsfellesskap er et begrep som brukes i forbindelse med kompetanseutvikling i et praksisfellesskap. Begrepet profesjonelle læringsfellesskap er hentet fra Stoll, Bolam, McMahon, Wallace og Thomas (2006), og Stoll og Louis (2007). Det fins ikke noen felles akseptert definisjon av profesjonelle læringsfellesskap. De to nevnte referansene baserer seg på omfattende litteraturgjennomganger, og konkluderer med å knytte begrepet til en gruppe yrkesutøvere som innenfor sin kollektive virksomhet deler og kritisk unders $\varnothing$ ker egen praksis. Profesjonelle læringsfellesskap kan også omtales som fellesskap for vedvarende utvikling og forbedring (Stoll m.fl., 2006). Det preges av at medlemmene viser gjensidig tillit og støtte, har felles verdier, visjoner og ansvar, og som gruppe samarbeider om reflekterte og undersøkende læringsmåter. At en gruppe deler visjoner og har felles oppfatninger av formålet med et endringsarbeid, har vist seg å være sentralt med tanke på å få til endringer i praksis (Andrews \& Lewis, 2007).

Det er ulike vinklinger innen forskning knyttet til begrepet profesjonelle læringsfellesskap. Noen er mest opptatt av hvordan profesjonelle læringsfellesskap kan medvirke til mer effektive organisasjoner. Andre er mer opptatt av kompetanseutvikling. Vi har hatt utvikling av veiledningskompetanse som utgangspunkt med tanke på å forbedre grunnlaget i fagmiljøet vårt for veiledning på masteroppgaver i matematikk i grunnskolelærerutdanning. Slik sett har vi hatt både en kompetanseutviklende og en effektiviserende vinkling. Kompetanseutvikling gjennom kollektiv læring handler om utvikling av læringsfellesskap. I gjennomføringen av vårt arbeid med å utvikle den kollektive læringen i vårt fagmiljø benyttet vi oss i læringsfelleskapet av case-analyser knyttet til reelle veiledningssituasjoner, refleksive og utforskende dialoger og felles planlegging som verktøy (Jensen \& Aas, 2011; Stoll m.fl., 2006; Wells, 1999).

Arbeidet i læringsfelleskapet vårt knytter vi til en forståelse av veiledning som en pedagogisk aktivitet, og det pedagogiske arbeidet er alltid i forandring, både i fellesskapsmedlemmets veiledning av student, og i fellesskapets kollegaveiledning. Steinsholt (2009) omtaler veiledning av studenter til å innebære utviklingen av en intuitiv profesjonalitet. Det handler om evnen til å utvikle nye tanker og handlingsalternativ som hjelper veilederen til å se hvilke handlinger som fungerer eller ikke fungerer. Veiledning kan altså sees som en prosess preget av deltakelse (for både veileder og student), og innebærer at man lærer og utvikler seg gjennom den sosiale og kulturelle deltakelsen. Dette innebærer at både veileder og den veiledede tolker og skaper mening i veiledningssituasjonen. Refleksive dialoger både $\mathrm{i}$ veiledning av student og i veilederfellesskapet støtter slik sett opp om det sosiale aspektet knyttet til konstruksjon av kunnskap (Brown \& Duguid, 2000; Säljö, 2006), hvilket vil si å utvikle nye tanker og handlingsalternativ sammen.

Å skape endringer handler om å bygge kollektiv kapasitet, dele feil og dele suksess (Hattie, 2013), og at levedyktige endringer starter med oss selv. Dette krever et samspill mellom individuelle og kollektive prosesser, noe som også bygger kompetanse og utvikler en organisasjon (Wells, 1999). Han skisserer videre en læringssyklus ut fra begrepene erfaring, informasjon, kunnskapsutvikling, innsikt og ny erfaring. Alle gjør sine unike, individuelle erfaringer. Når slike erfaringer deles med kollegaer, forblir ikke kunnskapen taus, men gjøres eksplisitt gjennom samhandling og dialog. Kollegaers deling av veiledningserfaringer i veiledermøter gir ikke nødvendigvis læring og utvikling. Ifølge Wells må man gjennom utforskende dialoger, der tenkingen blir synlig, søke å hente lærdom og bygge kunnskap ut fra de delte erfaringene. Hvordan man går videre fra deling til læring er altså et viktig knekkpunkt i utvikling av ny kompetanse. Wells ser kunnskap som sosialt distribuert mellom deltakerne i fellesskapet, og kollektive prosesser blir nødvendig for å utvikle ny kunnskap. Erfaringer fra deltakelse i den kollektive kunnskapsutviklingen kan føre til ny innsikt for den enkelte deltaker og danne grunnlaget for å gjøre nye erfaringer i neste steg. Wells sin modell viser flere former for utviklingsprosesser som utfyller hverandre og at kunnskapsutviklingen vil variere etter kvaliteten på de kollektive prosessene. 


\section{Veilederforum - tiltakets praktiske forankring}

Retningslinjene for FoU-oppgaver i grunnskolelærerutdanningene fastslår at FoU-oppgaven skal være et samarbeid mellom et skolefag (her: matematikk) og faget pedagogikk og elevkunnskap (PEL). Inspirert av teori om profesjonelle læringsfellesskap (Stoll m.fl., 2006) og Wells' (1999) læringssyklus for kompetansebygging og organisasjonsutvikling, etablerte vi et veilederforum i tilknytning til veiledningen av FoU-oppgavene i matematikk. Forumet besto av fire FoU-oppgaveveiledere fra matematikkmiljøet og en fagtilsatt fra PEL-faget. Representanten fra PEL-faget fungerte som moderator i veilederforumet, mens de fire veilederne fra matematikk fikk mulighet i forumsmøtene til å spille inn tema, situasjoner eller opplevelser med utgangspunkt i FoU-oppgavene de veiledet. Innspillene dannet grunnlag for refleksive og utforskende dialoger med mål om utvikling av nye tanker og handlingsalternativ og felles planlegging (Brown \& Duguid, 2000; Jensen \& Aas, 2011; Säljö, 2006; Steinsholt, 2009; Wells, 1999). Slike dialoger hadde vi for eksempel knyttet til studenters arbeid med å avgrense oppgaven sin og valg av metode. Vi hadde fire forumsmøter i løpet av perioden studentene arbeidet med FoU-oppgaven. På hvert møte inviterte moderatoren veilederne til å legge fram reelle tema, og helt ferske erfaringer og opplevelser, som forumet gjennom utviklende dialog søkte å utdype. I en del tilfeller resulterte veiledningssamtalene i konkrete handlingsalternativer som den enkelte veileder kunne ta med tilbake til studentveiledning.

\section{Metode}

Selvstudie er en form for praksisforskning eller undersøkelse (Clift, 2004; LaBoskey, 2004; Zeichner, 2007). I vårt opplegg involverte dette veiledere som reflekterte over egen praksis med mål om å forbedre egen og andres praksis. Vi søkte å forstå veilederpraksisen innenfra og ut, heller enn utenfra og inn, og iverksatte det vi lærte i vår veilederpraksis (Loughran, 2004). Vi la opp til en systematisk undersøkelse av praksis, basert på narrativer som grunnlag for analyse av tanker og erfaringer knyttet til veiledningsaktiviteten.

Artikkelforfatterne skrev til sammen ni narrativer, fordelt med tre på hver. I skrivingen baserte vi oss på Wells (1986) sin definisjon av narrativ til å være en fortelling, der fortellerformen brukes som et strukturerende hjelpemiddel for å skille ut det man opplever som relevant og organisere det $\mathrm{i}$ en form for logisk orden. I artikkelen bygger vi på Connelly og Clandinins (1990) forståelse av narrativet både som et fenomen og en forskningsmetode. Ved å være en informant ble det opp til den enkelte narrativskriver å legge fram virkeligheten slik den ble opplevd. Narrativet ble et fenomen fordi ordene som brukes har form som en personlig fortelling, og ble en metode når vi sammen skapte et nytt narrativ. Dette hjalp oss til å forstå helheten i prosessen vi gikk gjennom i arbeidet med å utvikle veiledningskompetanse. Hele forskningsprosessen - datainnsamling, analyse og skriving - ble med det en meningsskapende prosess.

For å svare på artikkelens problemstilling, nemlig å utvikle veiledningskompetanse, ble vi enige om at de tre narrativene skulle være knyttet til våre tanker og erfaringer til ulike faser i veiledningsarbeidet og deltakelse i veilederforum. I hvert narrativ dvelte vi ved et spørsmål, slik som vist i tabell 1 nedenfor. De tre spørsmålene ble utformet for å sette ord på og reflektere rundt egne opplevelser i veilederrollen og deltakelsen i utviklingsarbeidet. De to første narrativene ble skrevet mens veiledningsarbeidet pågikk, og det tredje etter at veiledningsarbeidet var avsluttet. 
Tabell 1. Tre narrativ; oppstart, midtveis, etterpå

\begin{tabular}{ccl}
\hline Tidspunkt & Narrativ & \multicolumn{1}{c}{ Spørsmål } \\
\hline Oppstart & 1 & $\begin{array}{l}\text { Hvilke tanker hadde du før oppstart av arbeidet med FoU-oppgaven } \\
\text { (muligheter, utfordringer, forventninger)? }\end{array}$ \\
Midtveis & 2 & $\begin{array}{l}\text { Hvilke erfaringer har du gjort så langt: } \\
\text { i møtet med veiledningsarbeidet? }\end{array}$ \\
Etterpå & 3 & Hvilke erfaringer har du gjort gjennom deltakelse i veilederforumet?
\end{tabular}

Narrativene gav oss data fra de tre rollene som var representert i veilederforumet; den erfarne veileder, den nye veileder og moderator. Vi leste og diskuterte de ni narrativene, og basert på denne prosessen skrev vi et samlet og helhetlig narrativ om hva vi ser som et grunnlag for å utvikle veiledningskompetanse, der vi kombinerer råtekstsitater fra enkeltnarrativer og rammetekst som vi skrev for å få fram våre resultater i form av synteser av tanker og erfaringer fra de tre rollene.

Når det er vi selv som har skrevet narrativene vi bruker, har vi utfordret etablert praksis knyttet til innhenting og analyse av data. Derfor har vi forsøkt å være tydelige og nøkterne i forskerrollen. Dette omtales som spesielt utfordrende knyttet til studier av egen praksis sett fra eget perspektiv (Hammersley, 2011), siden slike studier forutsetter veksling mellom innlevelse og analytisk distanse. Kvale og Brinkmann (2015) framhever imidlertid kunnskap om forskningstemaet og ekspertise innenfor det aktuelle feltet som forutsetninger for gyldige tolkninger. Som insidere i prosessene og leverandører av det benyttede datamaterialet tilfredsstiller vi denne fordringen. Dessuten har vi prøvd å oppfylle Feldmans (2003) fem validitetskrav:

1. Å gi klar og detaljert skildring av hvordan data er samlet inn, og være tydelig på hva som regnes som data. (Se metodedelen i artikkelen.)

2. Å gi klar og detaljert skildring av hvordan data blir presentert. (Se avsnittet som heter Grunnlaget for å utvikle veiledningskompetanse.)

3. Å bruke flere kilder som data. (Brukt flere sitater fra flere informanter. Se avsnittet som heter Grunnlaget for å utvikle veiledningskompetanse.)

4. Å vise hvorfor vi har valgt å samle inn og analysere data slik vi har gjort. (Se metodedelen i artikkelen.)

5. Å vise verdien av endringene av praksis. Dersom en selvstudie medfører endring i forskerens veiledningspraksis, så bør verdien av endringen synliggjøres. (Se avsnittet Oppsummering og veien videre til sist i artikkelen.)

\section{Noen overveielser vedrørende artikkelens form og innhold}

Før vi presenterer informantene og det helhetlige narrativet vil vi kommentere noen valg vi har gjort. I artikkelen har vi benyttet oss av litt utradisjonelle former for datainnsamling, analyse og presentasjon av resultater. Dette har vi valgt av flere grunner. For det første for å få frem våre opplevelser av kompleksiteten i veilederrollen har vi gitt stort rom til sitater som viser hvordan tre veiledere på ulike stadier i utviklingen av veilederkompetansen beskriver samme fenomener. For det andre har vi latt sitatene stå relativt ukommenterte for å understreke narrativene sine direkte budskap. For det tredje har vi som en følge av dette latt være å vie plass til forskningsetiske så vel som veilederetiske overveielser som for eksempel makt-ubalansen som kan være mellom de tre rollene den nye veileder, den erfarne veileder og moderator. Likeledes har vi ikke på detaljnivå gjort rede for dataanalysen, litteratursøk og nærmest utelatt validitets-/reliabilitetsproblematikk. Disse valgene har selvsagt betydning for artikkelens utforming. Vi har med andre ord valgt bort den strenge forskningsartikkelens form og krav til innholdsmomenter for bedre å appellere til leserens innlevelse og mulighet til selv å delta i dialogen med 
de tre rollene og dermed være medskaper i utviklingen av veilederkompetanse i eget fagmiljø. Altså har nøkternheten blitt redusert og det appellative forsterket, og dette valget mener vi er legitimt innenfor fagartikkelens rammer. I tillegg vil vi hevde at valgene kan øke innovasjonsviljen fordi dens forenklede fremstilling gjør det lettere for lesere ved andre institusjoner å kopiere vår tilnærming. I det minste har vårt eget opplevelsesaspekt stimulert oss til å fortsette utviklingsarbeidet med å bygge veilederkompetanse i vårt fagmiljø.

\section{Beskrivelse av informantene}

Den erfarne veileder har arbeidet med matematikk i lærerutdanning i nesten 20 år, og har lang og variert erfaring med oppgaveveiledning. Knyttet til FoU-oppgaven i matematikk vårsemesteret 2020 hadde han veiledningsansvar for 19 studenter.

Den nye veileder har arbeidet med matematikk i lærerutdanning i 3 år, og har lite erfaring med oppgaveveiledning. Knyttet til FoU-oppgaven i matematikk vårsemesteret 2020 hadde hun veiledningsansvar for 4 studenter.

Moderator har i likhet med den erfarne veileder lang og variert erfaring som veileder. Hans bakgrunn som pedagog skiller ham fra de andre medlemmene i veilederforumet. Han har ikke vært veileder for enkeltstudenter knyttet til FoU-oppgaven, men har stått til disposisjon for veilederne ved behov. I veilederforumet har han ledet de utforskende dialogene.

\section{Grunnlaget for å utvikle veiledningskompetanse}

Det samlede og helhetlige narrativet vi presenterer her dveler ved to hovedpunkter som utgjør sentrale svar på artikkelens spørsmål om hvordan et faglig læringsfellesskap kan utvikle kompetanse til å veilede gjennom erfaringsdeling og refleksjon rundt egen veilederrolle. Disse to hovedpunktene er betydningen av erfaring, trygghet, relasjon og ansvarsavklaring, og betydningen deltakelse i veilederforum. Vårt anliggende er å argumentere for at disse momentene må være til stede som et grunnlag for at et fagmiljø selv kan utvikle veiledningskompetanse gjennom veiledningsaktivitet, og at momentene må samlet ivaretas for at dette grunnlaget skal fungere.

\section{Betydningen av erfaring, trygghet, relasjon og ansvarsavklaring}

Det første møtet med en veiledningssituasjon som oppnevnt veileder mener vi nesten uten unntak er basert på personlig erfaring. Denne erfaringen er basert på egen fagkunnskap innenfor det fagfelt man arbeider, kontakt man har hatt med studenter gjennom undervisning, og veiledning man selv har fått som student på forskjellig nivå.

Den nye veileder:

Jeg sitter alltid med blandede følelse når jeg skal begi meg ut på oppgaver jeg aldri før har prøvd. På den ene siden er det spennende å prøve noe nytt, og jeg ser store muligheter for å utvikle meg selv. I rollen som faglærer i matematikk føler jeg meg trygg på det faglige innholdet, dette er noe jeg kan. I en veilederrolle er jeg mer på gyngende grunn, jeg kan ikke lenger støtte meg på faget alene. Slik jeg ser det må en veileder på en FoU-oppgave også ha god kunnskap om det å være forsker. Spesielt ser jeg på metode som et utfordrende område fordi jeg selv har begrenset kunnskap om dette temaet. Dette er noe jeg ønsker å bli bedre på, derfor har jeg lyst til å prøve meg i veilederrollen. På den andre siden er jeg redd for å ikke strekke til. Er jeg god nok for studentene?

Den erfarne veileder:

Veiledning er nok en av delene av mitt virke i akademia som er mest erfaringsbasert, og derfor er jeg av den oppfatning at jeg lærer noe nytt om veiledning, og utvikler min veilederrolle videre, i hvert veilederarbeid jeg er involvert i.

Graden av erfaring henger sammen med veiledningskvalitet, men det har også sterk betydning hva vi gjør med disse erfaringene. Vi mener at en del av veiledningsarbeidet er å lære av erfaringene man gjør. Det kan gi bekreftelser på hva man behersker godt, og hva man som veileder trenger å arbeide noe mer med. 
Faglige emner er en side av dette, men kommunikasjon med studenten, avklaring og oppfølging av forventninger og framdrift er eksempler på andre sider som krever oppmerksomhet fra veilederen. Vi har følt på at det vil variere hva den enkelte veileder kjenner på som utfordrende og som trygt. Dette kommer blant annet til uttrykk gjennom de tanker og erfaringer veilederen har om veiledningsaktiviteten.

Den erfarne veileder:

Møtet med studentene har svart omtrent til forventningene. Det er stort sprik i ambisjoner, og gjennomgående behov for å hjelpe til med å avgrense arbeidet. Jeg synes også at mange av studentene skriver ganske godt, men det er også skrivingen som virker til å være det vanskeligste arbeidet for mange.

Den nye veileder:

Jeg synes veilederrollen har endret karakter gjennom semesteret, og jeg vil dele det inn i tre faser. I den første introduserende fasen følte jeg at studentene var usikre på mulighetene og begrensningene knyttet til oppgaven. Her var det naturlig å gå inn i en lyttende rolle og prøve å begrense mange av de store tankene studentene hadde til eget prosjekt. Jeg synes det var nyttig at studentene hadde en tidlig frist for levering av prosjektskisse, slik at de fikk bestemt seg for en retning for oppgaven. I den neste fasen ble jeg utfordret på metode og teorigrunnlag. Det var interessant å høre hvordan studentene hadde tenkt å finne svar på problemstillingene sine. Jeg gikk over til å bli en samtalepartner som de så til for bekreftelse eller svar. Her følte jeg meg usikker ved flere anledninger og søkte tidvis råd hos kollegaer. Jeg håper erfaring vil gjøre meg tryggere i denne fasen. Det var også utfordrende å formidle mine synspunkter til studentene på en slik måte at veiledningen ble oppfattet slik jeg hadde tenkt. Det var flere anledninger der de tok alt jeg sa for god fisk, noe som overrasket meg. I den tredje og siste fasen var arbeidet med oppgaven kommet så langt at det var mulig å gi veiledning på skriftlig materiale. I dette arbeidet følte jeg en helt annen ro. Det kom tydelig fram hva studentene hadde utfordringer med, og det var god tid til å sjekke opp elementer jeg selv var usikker på.

I et veiledningsløp viser det seg, med nyanser selvsagt, at utfordringene ofte er de samme for studentene. Alle skal gjennom en planleggingsfase, en gjennomføringsfase og en dokumentasjonsfase, og parallelt med dette er det en prosess som omfatter studentens forventninger, forutsetninger, og struktur på eget arbeid. Dette er noe som i ethvert veiledningsløp vil kreve oppmerksomhet, om enn i varierende grad. $\emptyset$ kende erfaring med de ulike delene av veiledningsløpet mener vi er med på å gjøre veilederen trygg i rollen.

Den nye veileder:

I oppstarten framstod studentene som nølende, de virket usikre på eget arbeid. Jeg følte at mine forslag ble kjærkomment mottatt, de hørte på det jeg sa. En utfordring her var at med en gang jeg foreslo en ny vinkling, byttet hele oppgaven retning uten en god diskusjon. Det har vært utfordrende å vite i hvor stor grad man skal styre oppgaven uten å ta fra studentene selvstendigheten.

\section{Moderator:}

Med så mange studenter som skal veiledes, forventet eller fryktet jeg at det kunne bli noen utfordrende veiledningsrelasjoner hvor det kunne bli aktuelt å skifte veileder.

Vi ser den gjensidige opplevelsen av å bli tatt på alvor og kunne kommunisere godt som det grunnleggende stadiet for etablering av en relasjon som gjør veiledningen til et faglig verdifullt samarbeid mellom student og veileder. Samtidig blir vi av og til overrasket over hvor lett studenten følger innspill fra veileder. Det gir oss en påminnelse om hvor viktig det er at veileder ikke overtar prosjektet det veiledes på, men at det ansvaret forblir studenten sitt.

\section{Betydningen av deltakelse i veilederforum}

For at samarbeidet mellom veilederne skal oppleves som verdifullt (Andrews \& Lewis, 2007; Stoll, m.fl, 2006), mener vi at gode relasjoner i fagmiljøet er nødvendig. Man skal vite at det foreligger en ærlig og grunnleggende holdning hos alle til at dine utfordringer knyttet til en veiledningssituasjon er like mye mine utfordringer. Det betyr at vi sammen ser etter måter å håndtere dette på. Da vil man lettere få del $\mathrm{i}$ et mangfold av erfaringer og enklere få råd om hvordan veiledningssituasjoner kan håndteres.

Den erfarne veileder: 
Når det gjelder mine veilederkollegaer, vil jeg si at jeg forventet at de hadde ambisjoner om både å være veileder og å lære å veilede.

Den nye veileder:

Videre ble det sagt at veilederne i emnet skulle samarbeide, dette er noe jeg forventer at følges opp. (...). Jeg har gode erfaringer fra tidligere samarbeid med de fleste veilederne, noe som gjør at jeg har tro på at samarbeidet kan fungere. Jeg tror det vil være lav terskel for å spørre om tips og råd i dette arbeidet.

\section{Moderator:}

Jeg hadde ikke tidligere arbeidet med tre av veilederne, og var noe usikker på hvor åpne og ærlige de ville være overfor meg, og hvor villige de ville være til å vise usikkerhet og sårbarhet. Hvor høy ville takhøyden vise seg å være for å diskutere og håndtere utfordrende spørsmål?

Vi hadde forventninger til at det profesjonelle læringsfelleskapet skulle utvikle seg gjennom deltakelse i veilederforumet, og at relasjonene mellom forummedlemmene skulle bli styrket. Disse vi til bevisstgjøringen om et kollektivt veiledningsperspektiv, som verdifullt for utvikling av individuell veiledning. Dette så vi eksempler på i veiledernes beskrivelser av erfaringer med å delta i veilederforumet.

Den nye veileder:

Jeg har som forventet hatt noen utfordringer knytt til metode, her har jeg hatt god støtte i [Moderator] som har deltatt på deler av veiledningen etter $\emptyset$ nske fra meg. Jeg føler at jeg blottlegger mine svakheter overfor studentene, men for studentene tror jeg det oppfattes som om det er to veiledere som er inne på oppgaven. Disse samtalene har jeg lært mye av. Jeg føler at vi står sammen om veiledningsarbeidet, noe jeg også forventet i forkant.

\section{Den erfarne veileder:}

(...) jeg tenker nok at hans [Moderator] frie veilederposisjon er mest verdifull gjennom at den gjør at han alltid er tilgjengelig og kan involvere seg fritt og med nye, men veiledererfarne øyne og ører, i store og små spørsmål studentene og vi som veileder diskuterer.

\section{Den nye veileder:}

Jeg var positiv til et veilederforum ved oppstart fordi jeg tenkte det ville gi mulighet til å få tips og råd knyttet til veiledning. Allerede ved første møtepunkt var det klart at å være veileder på FoU-oppgaven skulle være en felles oppgave der ingen stod alene, dette gav trygghet. Vi har hatt noen faste møtepunkt der vi har fått diskutert ulike problemer som dukket opp underveis, men veilederforumet har også invitert til samtale utenfor gitte møtetidspunkt. For min del har samtalene utenom møtene vært like viktige.

Vi mener at veilederforumet må kjennetegnes av en kultur hvor det oppleves som trygt å vise sin usikkerhet eller sårbarhet og hvor det er rom for faglige diskusjoner som utfordrer ens egen forståelse. Det er en styrke for fagmiljøet at alle legger fram opplevde problemstillinger, og at man gjennom utforskende og reflekterende dialoger i veilederforumet søker å utvikle veilederkompetansen for hele fagmiljøet.

Den erfarne veileder:

Jeg har erfart at et slikt veilederforum kan fungere godt, men som med alle andre møtepunkt krever det at alle prioriterer deltakelse, og får kjenne på betydningen av sin deltakelse. Derfor fungerer det, etter min mening, aller best når alle deltakerne basert på egne erfaringer kan bevege seg bort fra lytter- og mottakerposisjon, og naturlig innta posisjon som deler av erfaring og tilbyder av råd til løsninger på utfordringer som legges fram av andre. For min del betydde dette at jeg, sammen med Moderator, tok en del ansvar for å fremme diskusjonstema på de to første forumsmøtene, da vi da fremdeles var i studentenes utviklings- og gjennomføringsfaser av sine oppgaveprosjekt, mens dette endret seg i de to siste møtene. Da hadde studentene begynt å arbeide med egne data og produksjon av tekst. Jeg opplevde i de to siste møtene at alle hadde større trygghet i veilederrolla, kanskje fordi data og tekst er mer håndfast å forholde seg til, og kanskje fordi forumets funksjon hadde satt seg litt bedre blant oss som utgjorde forumet. I alle fall opplevde jeg at erfaringsforskjellene ble mer visket ut, og vi ble mer likestilte bidragsytere.

\section{Moderator:}


Mitt inntrykk er at veilederforumet har fungert som en støtte og en trygghet slik det var tenkt. Jeg tenker at det vil være nyttig uavhengig av om veilederne er erfarne eller uerfarne. Her er det mulig å diskutere konkrete og mer generelle problemstillinger knyttet til veiledning. Jeg tenker at forumet fungerer best når alle deltar aktivt og det er en diskusjon med utgangspunkt i en reell veiledningsdiskusjon som alle kan lære av. Det tror jeg bare vi delvis har fått til.

Den nye veileder:

På de faste møtepunktene har de mer erfarne veilederne i forumet hatt en naturlig styring på diskusjonen. Dette synes jeg har vært greit. Gjennom mangfoldige diskusjoner har jeg fått tatt opp problemer jeg har møtt på som veileder, dette har vært kjempenyttig og lærerikt. Jeg føler dessverre at mitt bidrag til de andre i forumet ikke har vært noe særlig. Jeg har tidvis følt at jeg har lite å komme med, og derfor fått en mer passiv rolle. Her kunne jeg selvsagt prøvd å ta mer plass, men innspillene har gjerne kommet før jeg har fått tenkt nok på problemstillingen.

Vi mener videre at en sirkulær, kollektiv læringsprosess med flere faser sjelden fungerer best ved første gangs gjennomføring, selv om man sitter med et positivt inntrykk etter å ha gjennomført prosessen èn gang.

Den nye veileder:

Det har vært et spennende og variert arbeid, der jeg i rollen som veileder har kjent på følelsen av å ikke ha kontroll. Med dette mener jeg ikke kontroll over strukturen, for her synes jeg det har vært klare retningslinjer og tydelige planer for å føre arbeidet med FoU-oppgavene framover (to eksempler på dette kan være innlevering av prosjektskisse og midtveisseminar), og ikke minst god støtte i kollegaer. (...). Jeg synes veiledningen dette semesteret har gått bra og gleder meg til fortsettelsen!

\section{Moderator:}

Jeg er like overbevist som i oppstarten om at et slikt forum potensielt kan være en styrke for alle parter, men formen bør justeres.

Den erfarne veileder:

Jeg håper at denne samarbeidsstrukturen kan fortsette, for forumet vil fungere enda bedre ettersom tryggheten i veilederrollen $\emptyset$ ker. Tid og kontinuitet vil gjøre opplevelsen av deltakelse i veilederforumet mer likeverdig, noe som igjen gjør Moderator sin funksjon mindre utfordrende, og alles trygghet i veilederrollen sterkere. Samtidig tror jeg at forumet også vil ha en edruelig påvirkning på den enkeltes oppfatning av egen veilederrolle og egne valg som veileder, slik at man også bevarer en nødvendig ydmykhet i forhold til rollen som veileder og til veiledningsarbeidet.

Vi har forventninger til videreføring av den kollektive tilnærmingen til å forstå hvordan veiledningskompetanse kan utvikles både i fagmiljøet og hos den enkelte veileder. Derfor $\emptyset$ nsker vi å fortsette utviklingen av veiledningskompetanse gjennom veiledningsaktivitet.

\section{Individuell og kollektiv veiledningskompetanse}

Beskrivelsene og sitatene ovenfor viser hvordan grunnlaget bidrar til både utvikling av individuell og kollektiv veiledningskompetanse. En slik utvikling viser hvordan Wells' (1999) læringssyklus (erfaring, informasjon, kunnskapsutvikling, innsikt og ny erfaring) gir fellesskapet ny kunnskap om veiledning. For den enkelte veileder handler det om å kjenne seg trygg på at man gjør det beste man kan for studenten innenfor de ressursrammer som er gitt og om å være bevisst at man stadig utvikler seg som veileder. Videre antyder det helhetlige narrativet hvordan det organisatorisk kan legges til rette for utvikling av en kollektiv kultur for samarbeid om veiledning (jf. Brown \& Duguid, 2000; Säljö, 2006; Wells, 1999). Dette er uavhengig av om man har erfaring med veiledning eller ei. For fagmiljøet handler etableringen av et slikt profesjonelt læringsfelleskap konsentrert om veiledningsarbeidet (Stoll et. al, 2006) om å utvikle miljøets kollektive veiledningskompetanse. Kort og godt utnytter man fagmiljøets iboende veiledningskompetanse og dets vilje til kollektiv kunnskapsutvikling innenfor egen kontekst. 


\section{Oppsummering og veien videre}

I denne artikkelen argumenterer vi for at veiledning ikke er en aktivitet som veilederen behøver å utvikle alene. Bruk av et veilederforum, preget av erfaringsdeling, stabile relasjoner, trygghet og tydelig ansvarsavklaring, ser ut til å gjøre byggingen av god veiledningskompetanse kortere og mindre utsatt og tilfeldig. Kollektive læringsprosesser innebærer at man må være i stand til å legge fram erfaringer, problemstillinger og tema der man er utrygg eller usikker, og åpne opp for å belyse dem med kritisk refleksjon. Da kan ny innsikt skape flere måter å forstå på og handle på.

Målet med arbeidet vårt har vært å utvikle veiledningskompetanse i et læringsfellesskap. Vi ser at dette arbeidet har fått en god start. Det neste steget for vår del, er å utvide det profesjonelle læringsfellesskapet til å omfatte alle i matematikkseksjonen ved HVL - Campus Sogndal, slik at alle involveres i den kollektive kunnskapsutviklingen knyttet til veiledningsarbeid. Det gjør vi i første omgang gjennom at alle i fagmiljøet er FoU-oppgaveveiledere høsten 2020 og deltar i et veilederforum. Det neste steget vil være å gjøre det samme knyttet til masteroppgaveveiledning. Alle kan utvikle sin individuelle veiledningskompetanse, og alle $\mathrm{i}$ et fagmiljø kan være med og påvirke utviklingen av en kollektiv kultur for kunnskapsutvikling og samarbeid om veiledning. Etablering av en slik forståelse og struktur for kunnskapsutvikling i fagmiljøet vil etter vår oppfatning gjøre oss bedre rustet til å møte $\varnothing$ kningen av masterveiledningsarbeid som venter fra høsten 2021.

\section{Referanser}

Andrews, D. \& Lewis, M. (2007). Transforming practice from within: the power of the professional learning community. In L. Stoll \& K.S. Louis (Eds.), Professional Learning Communities. Divergence, Depths and Dilemmas. (pp. 132-147). Berkshire: Open University Press.

Brown, J.S. \& Duguid, P. (2000). The Social Life of Information. Cambridge: Harvard Business School Press.

Clift, R. T. (2004). Self-study research in the context of teacher education programs. In J. J.

Loughran, M. L. Hamilton, V. K. LaBoskey \& T. Russell (Eds.), International handbook of self-study of teaching and teacher education practices (pp. 1333 - 1366). Dordrecht: Kluwer Academic Publishers. https://doi.org/10.1007/978-1-4020-6545-3 35

Connelly, M. \& Clandinin, J. (1990). Story of experience and narrative inquiry. Educational Researcher 19(5), 2-14. https://doi.org/10.3102/0013189x019005002

Feldman, A. (2003). Validity and quality in self-study. Educational Researcher, 32(3), 26-28. https://doi.org/10.3102/0013189X032003026

Hammersley, M. (2011). Methodology: who needs it? Los Angeles: Sage. https://doi.org/10.4135/9781446287941

Hattie, J. (2013). Synlig læring - for lærere. Oslo: Cappelen Damm Akademisk.

Jensen, R. \& Aas, M. (2011). Å utforske praksis. Oslo: Cappelen Damm Akademisk.

Kvale, S. \& Brinkmann, S. (2015). Det kvalitative forskningsintervju (3. utg.). Oslo: Gyldendal Akademisk.

LaBoskey, V. K. (2004). The methodology of self-study and its theoretical underpinnings. In

J. J. Loughran, M. L. Hamilton, V. K. LaBoskey, \& T. Russell (Eds.), International handbook of selfstudy of teacher education practices (pp. 817-869). Dordrecht: Kluwer Academic Publishers. https://doi.org/10.1007/978-1-4020-6545-3 21

Loughran, J. J. (2004). Learning through self-study: The influence of purpose, participants and context. In J. J. Loughran, M. L. Hamilton, V. K. LaBosky, \& T. Russell (Eds.), International handbook of self-study of teaching and teacher education practices (pp. 151-192). Dordrecht: Kluwer Academic Publishers. https://doi.org/10.1007/978-1-4020-6545-3 5

Steinsholt, K. (2009). Evidensbaserte standarder eller profesjonalitet? Bedre Skole, 1, 54 - 62. 
Stoll, L., Bolam, R., McMahon, A., Wallace, M., \& Thomas, S. (2006). Professional learning communities: a review of the literature. Journal of Educational Change, 7, 221- 258. https://doi.org/10.1007/s10833-006-0001-8

Stoll, L. \& Louis, K. S. (Eds.) (2007). Professional Learning Communities. Divergence, Depth and Dilemmas. Berkshire: Open University Press.

Säljö, R. (2006). Læring og kulturelle redskaper. Om læreprosesser og den kollektive hukommelsen. Oslo: Cappelen Akademisk.

Wells, C. (1986). The meaning makers. London: Hodder and Stoughton.

Wells, G. (1999). Dialogic Inquiry. Towards a Sociocultural Practice and Theory of Education. New York, NY: Cambridge University Press.

Zeichner, K. (2007). Accumulating knowledge across self-studies in teacher education. Journal of Teacher Education, 58(1), 36-46. https://doi.org/10.1177/0022487106296219 